\title{
Impact of Integrated Nutrient Management on Wilt Incidence of Isabgol (Plantago ovata Forsk.) under Northern Dry Zone of Karnataka
}

\author{
Siddalingayya V. Salimath ${ }^{*}$, K. N. Kattimani, Y. K. Kotikal, \\ D. R. Patile and N. S. Nagarja, Jameel Jhalegar and J. Venkatesh \\ College of Horticulture, University of Horticultural Sciences, Bagalkot, India \\ *Corresponding author
}

\begin{abstract}
A B S T R A C T
Keywords

Gujarat Isabgol-2, Vallabh Isabgol-1 and Wilt

Article Info

Accepted:

27 November 2020

Available Online:

10 December 2020

\section{Introduction}

In India, Isabgol occupies an area of 80,000 ha with the total production of 45,000 tonnes and productivity of $0.56 \mathrm{MT} \mathrm{ha}^{-1}$. India is the only country with monopoly in Isabgol production and marketing in the international trade. Thus, with average export volume of $29,000 \mathrm{MT}$ and it earns on an average of ₹ 520 crores annually which contribute to about 80 per cent of the Psyllium traded in the world market. So, it is called as dollar earning medicinal plant of India. Among all the countries in the world, the United States of America is the single major buyer of Psyllium husk from India, accounting for about 75 per
\end{abstract}

The field studies were conducted to evaluate the wilt diseases parameters of two Isabgol cultivars for commercial production in northern dry zone of Karnataka during two years 2015-16 and 2016-17. The experiment was laid out in split plot design (SPD) with sixteen INM treatment combinations at the college of horticulture, Bagalkot. Analysis of both years with pooled data exhibited higher value was recorded in Vallabh Isabgol-1 with wilt incidence as compared to Gujarat Isabgol-2. Whereas the higher wilt incidence values in integrated nutrient management treatments with respect parameters were observed in treatment $\mathrm{N}_{11}\left(75 \%\right.$ RD of FYM $\left(7.5 \mathrm{tha}^{-1}\right)+75 \%$ RD of NPK $\left(37.5: 18.75: 22.50 \mathrm{~kg} \mathrm{ha}^{-1}\right)$ + Azospirillum $\left(5 \mathrm{~kg} \mathrm{ha}^{-1}\right)+\operatorname{PSB}\left(3 \mathrm{~kg} \mathrm{ha}^{-1}\right)+\mathrm{ZnSO}_{4}\left(15 \mathrm{~kg} \mathrm{ha}^{-1}\right)+\mathrm{FeSO}_{4}\left(7.5 \mathrm{~kg} \mathrm{ha}{ }^{-1}\right)$. Higher wilt incidence on interaction effect on growth parameters were recorded in $\mathrm{V}_{1} \mathrm{~N}_{11}$. cent of the total exports of the material from India (Goraya and Ved, 2019) with annual trade of more than $60,000 \mathrm{MT}$.

Several diseases were reported in Isabgol from India and other parts of the world. Fusarium wilt (Fusarium oxysporum Schlecht.), which was reported from Arizona, North America (Russell, 1975) as well as from Haryana (Mehta et al., 1985).

Elwakil and Ghoneem (1999) reported 41 species of fungi belonging to 21 genera from seed samples of blond psyllium reported from Egypt. They proved the pathogenic nature of Fusarium oxysporum, Fusarium solani and 
Fusarium moniliforme with Isabgol seeds and seedlings.

Mandalet et al., (2008) opined that different doses of inorganic nutrients had considerable influence on growth and yield with downy mildew interaction in Isabgol. The study included three levels of nitrogen $(0,30,60 \mathrm{~kg}$ $\left.\mathrm{N} \mathrm{ha}^{-1}\right)$, two levels of phosphorous $(0,30 \mathrm{~kg} \mathrm{P}$ $\left.\mathrm{ha}^{-1}\right)$ and two levels of potash $(0,40 \mathrm{~kg} \mathrm{~K} \mathrm{ha}$ $\left.{ }^{1}\right)$. The highest $\mathrm{N}$ supply $\left(60 \mathrm{~kg} \mathrm{ha}^{-1}\right)$ caused more than 65 per centage disease severity. Seed yield was influenced by $\mathrm{N}$ but not by $\mathrm{P}$ or K. In both years, the highest seed yield was obtained from $60 \mathrm{~kg} \mathrm{ha}{ }^{-1} \mathrm{~N}$ application. According to Patel (2014), among 15 germplasm Isabgol screened none was found completely free from infection of downy mildew. HI-5 and HI-2 were found highly susceptible, whereas UR-188, MBN-29, JI83, Niharika and MB-322 which shown resistant to minimum per cent disease intensity. Screening of 10 promising genotypes against downy mildew, bacterial blight, leaf spot, blight and root rot revealed that five genotypes of Isabgol (P-80, P6, PB3-1, AMB2, and MIB-124) showed resistance against these diseases (Anon. 2015a). Talaviya et al., (2017) screened cumin variety lines against wilt disease to find out the resistant of cultivars per lines. Out of fifteen varieties per lines tested one line (JC2000-9) was found free from disease. The recommended varieties of Gujarat State viz., GC-2, GC-3 and GC-4 were found highly susceptible to $F$. oxysporum $f$. sp. cumini under present investigation. Thirty coriander genotypes/varieties were screened against Fusarium oxysporum under artificial inoculation conditions in field. On the basis of two years observations, it was recorded that four of the genotypes/varieties were resistant (R) RCr446, RCr-684, RCr-20, RCr-41 were categorized, nineteen genotypes/varieties viz. like RCr-475, RCr480, RCr-728, UD-796 etc. and RD-154 as moderately resistant, four genotypes/varieties viz., NS-1, J.Co-387, Co2, and UD-529 as susceptible and rest three genotype/varieties viz., RCr-435, RCr-446, DH-205 as highly Susceptible (Jat and Ahir. 2017).

\section{Materials and Methods}

The field experiment was conducted at Department of Plantation Spices Medicinal and Aromatic Plants, College of Horticulture, Bagalkot at Haveli farm during the years 2015-16 and 2016-17.

Geographically, this experimental site lies in Northern Dry Zone (Zone-3) of Karnataka state in the agro-climatic zone of Karnataka, situated at $16^{\circ}$ North latitude and 74'59' East longitude and at an altitude of $533.0 \mathrm{~m}$ above mean sea level. The soil of experimental field was red clay loamy in texture, with percentages of sand 22.60, silt 26.10 and clay52.20 bulk density 1.25 , EC $0.24 \mathrm{dS} \mathrm{m}^{-1}$ and $\mathrm{pH} 8.22$ (alkaline in reaction) with organic carbon 1.63 and available 268.02, 34.80, 273.69 NPK kg ha' . The source of seed collection was DMAPR Anandh Gujarat i.e. Vallabh Isabgol-1( $\left(\mathrm{V}_{1}\right)$ and Gujarat Isabgol-2 $\left(\mathrm{V}_{2}\right)$. Seed were sown in 18 November 2015 and 2016 with gross plot size of $3.6 \mathrm{~m} \mathrm{x} 1.5 \mathrm{~m}=5.40 \mathrm{~m}^{2}$ in split plot design in sixteen INM sub treatments with three replications as subplot listed below.

$\mathrm{N}_{1}$-RDF FYM $\left(10 \mathrm{t} \mathrm{ha}^{-1}\right)+$ RDF NPK
$\left(50: 25: 30 \mathrm{~kg} \mathrm{ha}^{-1}\right)$ $\mathrm{N}_{2}$-RDF FYM (0 $\left.\mathrm{t} \mathrm{ha}^{-1}\right)+$ RDF NPK $\left(50: 25: 30 \mathrm{~kg} \mathrm{ha}^{-1}\right)+\mathrm{ZnSo}_{4}\left(15 \mathrm{~kg} \mathrm{ha}^{-1}\right)$

$\mathrm{N}_{3}$-RDF FYM (10 $\left.\mathrm{t} \mathrm{ha}^{-1}\right)+$ RDF NPK $\left(50: 25: 30 \mathrm{~kg} \mathrm{ha}^{-1}\right)+\mathrm{FeSo}_{4}\left(7.5 \mathrm{~kg} \mathrm{ha}^{-1}\right)$

$\mathrm{N}_{4}$-RDF FYM (10 $\left.\mathrm{t} \mathrm{ha}^{-1}\right)+$ RDF NPK $\left(50: 25: 30 \mathrm{~kg} \mathrm{ha}{ }^{-1}\right)+\mathrm{FeSo}_{4} \quad\left(7.5 \mathrm{~kg} \mathrm{ha}{ }^{-}\right.$ $\left.{ }^{1}\right)+\mathrm{ZnSo}_{4}\left(15 \mathrm{~kg} \mathrm{ha}^{-1}\right)$ 
$\mathrm{N}_{5}$-Vermicompost $\left(1 \mathrm{t} \mathrm{ha}{ }^{-1}\right)+$ RDF NPK (50:25:30 kg ha')

$\mathrm{N}_{6}$-Vermicompost $\left(1 \mathrm{t} \mathrm{ha}^{-1}\right)+50 \%$ RDF NPK $\left(50: 25: 30 \mathrm{~kg} \mathrm{ha}^{-1}\right)+$ Azospirillum $\left(5 \mathrm{~kg} \mathrm{ha}^{-1}\right)+$ Azotobacter $\left(5 \mathrm{~kg} \mathrm{ha}^{-1}\right), \mathrm{N}_{7}-75 \%$ RDF FYM $\left(7.5 \mathrm{t} \mathrm{ha} \mathrm{h}^{-1}+75 \%\right.$ RDF NPK (37.5:18.75:22.50 $\left.\mathrm{kg} \mathrm{ha}^{-1}\right)$

$\mathrm{N}_{8}-75 \%$ RDF FYM $\left(7.5 \mathrm{t} \mathrm{ha}^{-1}\right)+75 \%$ RDF NPK $\quad\left(37.5: 18.75: 22.50 \quad \mathrm{~kg} \quad \mathrm{ha}^{-1}\right) \quad+$ Azotobacter $\left(5 \mathrm{~kg} \mathrm{ha}^{-1}\right) \mathrm{N}_{9}-75 \%$ RDF FYM $\left(7.5 \mathrm{t} \mathrm{ha}^{-1}\right)+75 \%$ RDF NPK $\left(37.5: 18.75: 22.50 \mathrm{~kg} \mathrm{ha}^{-1}\right)+$ Azospirillum $(5 \mathrm{~kg}$ $\mathrm{ha}^{-1}$ )

$\mathrm{N}_{10}-75 \%$ RDF FYM $\left(7.5 \mathrm{t} \mathrm{ha}^{-1}\right)+75 \%$ RDF NPK $\left(37.5: 18.75: 22.50 \mathrm{~kg} \mathrm{ha}^{-1}\right)+P S B(3 \mathrm{~kg}$

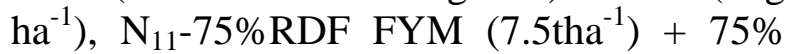
RDF NPK (37.5:18.75:22.50 kg ha $\left.{ }^{1}\right)+$ Azospirillum $\left(5 \mathrm{~kg} \mathrm{ha}^{-1}\right)+P S B \quad(3 \mathrm{~kg}$ ha $\left.{ }^{1}\right)+\mathrm{ZnSo}_{4}\left(15 \mathrm{~kg} \mathrm{ha}^{-1}\right)+\mathrm{FeSo}_{4}\left(7.5 \mathrm{~kg} \mathrm{ha}^{-1}\right)$

$\mathrm{N}_{12}-50 \%$ RDF FYM $\left(5 \mathrm{tha}^{-1}\right)+50 \%$ RDF NPK (25:12.5:15 NPK kg ha $\left.{ }^{-1}\right)$

$\mathrm{N}_{13}-50 \%$ RD FYM $\left(5 \mathrm{tha}^{-1}\right)+50 \%$ RDF NPK $\left(25: 12.5: 15 \mathrm{~kg} \mathrm{ha}^{-1}\right)+$ Azotobacter $\left(5 \mathrm{~kg} \mathrm{ha}^{-1}\right)$, $\mathrm{N}_{14}-50 \%$ RDF FYM $\left(5 \mathrm{tha}^{-1}\right)+50 \%$ RDF NPK (25:12.5:15 $\left.\mathrm{kg} \mathrm{ha}^{-1}\right)+$ Azospirillum $(5 \mathrm{~kg}$ $\mathrm{ha}^{-1}$ )

$\mathrm{N}_{15}-50 \%$ RDF FYM $\left(5 \mathrm{t} \mathrm{ha}^{-1}\right)+50 \%$ RDF NPK $\left(25: 12.5: 15 \mathrm{~kg} \mathrm{ha}^{-1}\right)+P S B\left(3 \mathrm{~kg} \mathrm{ha}^{-1}\right)$

$\mathrm{N}_{16}-50 \%$ RD FYM $\left(5 \mathrm{tha}^{-1}\right)+75 \%$ RDF NPK (37.5:18.75:22.50 kg ha $\left.{ }^{-1}\right)+$ Azospirillum $\left(5 \mathrm{~kg} \mathrm{ha}^{-1}\right)+P S B\left(3 \mathrm{~kg} \mathrm{ha}^{-1}\right)+\mathrm{Znso}_{4} \quad(15 \mathrm{~kg}$ $\left.\mathrm{ha}^{-1}\right)+\mathrm{FeSo}_{4}\left(7.5 \mathrm{~kg} \mathrm{ha}^{-1}\right)$.

The experiment after layout then treatments were applied as per above nutrient combination, then mixed thoroughly in plots before imposing the treatments. Zinc was applied in the form of $\mathrm{ZnSo}_{4}$ at the time of sowing half dose of $\mathrm{N}$ was applied as a basal and remaining half was applied one month after sowing as top dressing full dose of $\mathrm{P}$ and $\mathrm{K}$ were applied at the time of sowing below the seed in furrows made with the help of land hoe.

Manual thinning weeding and hoeing were done at one month after sowing to provide an ideal environment to the crop a light irrigation was given immediately before sowing, however six and seven irrigation were given as pet requirement of the crop with the help of sprinkler.

The pooled data was subjected to statistical analysis of split-plot design by the Fischer's method of analysis of variance technique as given by Panse and Sukhatme (1983). The level of significance used in ' $F$ ' and' $t$ ' test was $\mathrm{p}=0.05$, critical values were calculated wherever the ' $F$ ' test was significant. Scoring for wilt (Fusarium oxysporum) (Sagar and Jindla, 1984) disease incidence was recorded at natural field condition at different stages of crop growth $(30,60$, and 90 DAP) for two years. The scoring was done by using the scale 1 to 5 (Rathore and Pathak, 2001).

0 . Healthy plants (no symptoms) 1 .

1. 20 per cent plant leaf area covered 2 .

2. $>20-40$ per cent plant leaf area covered

3. 3. > 40-60 per cent plant leaf area covered

4. 4. > 60-80 per cent plant leaf area covered

5. > 80 per cent and above leaf area affected

\begin{tabular}{|l|l|}
\hline Scale & Reaction \\
\hline $\mathbf{0}$ & Immune \\
\hline $\mathbf{1}$ & Resistant (R) \\
\hline $\mathbf{2}$ & Moderately Resistant (MR) \\
\hline $\mathbf{3}$ & Susceptible (S) \\
\hline $\mathbf{4}$ & Highly Susceptible (HS) \\
\hline
\end{tabular}


Table.1 Wilt infestation as influenced by Isabgol varieties and integrated nutrient management (0-5 scale)

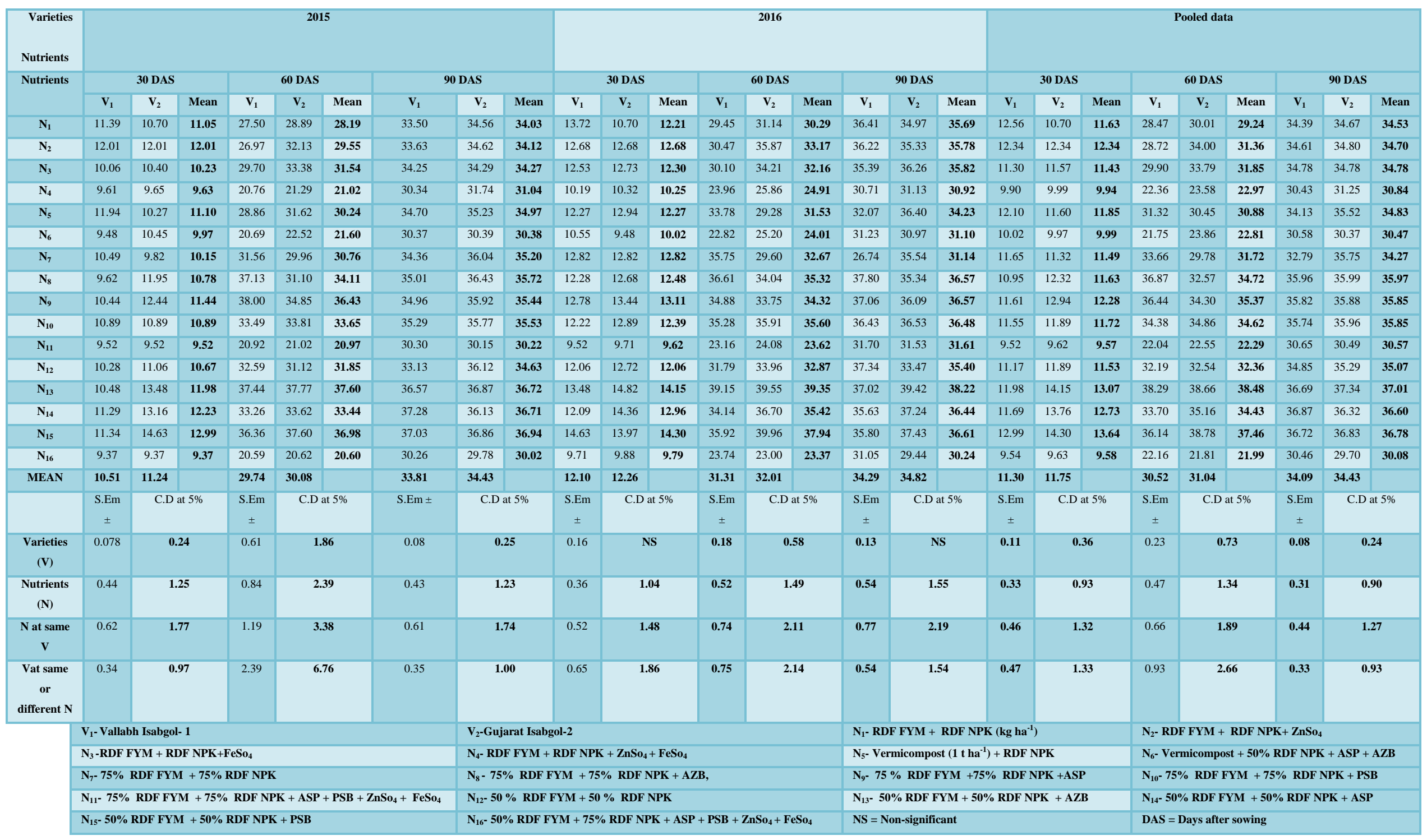


Fig.1 Effect of varieties and integrated nutrient management on wilt incidence of Isabgol (Plantago ovata Forsk.)

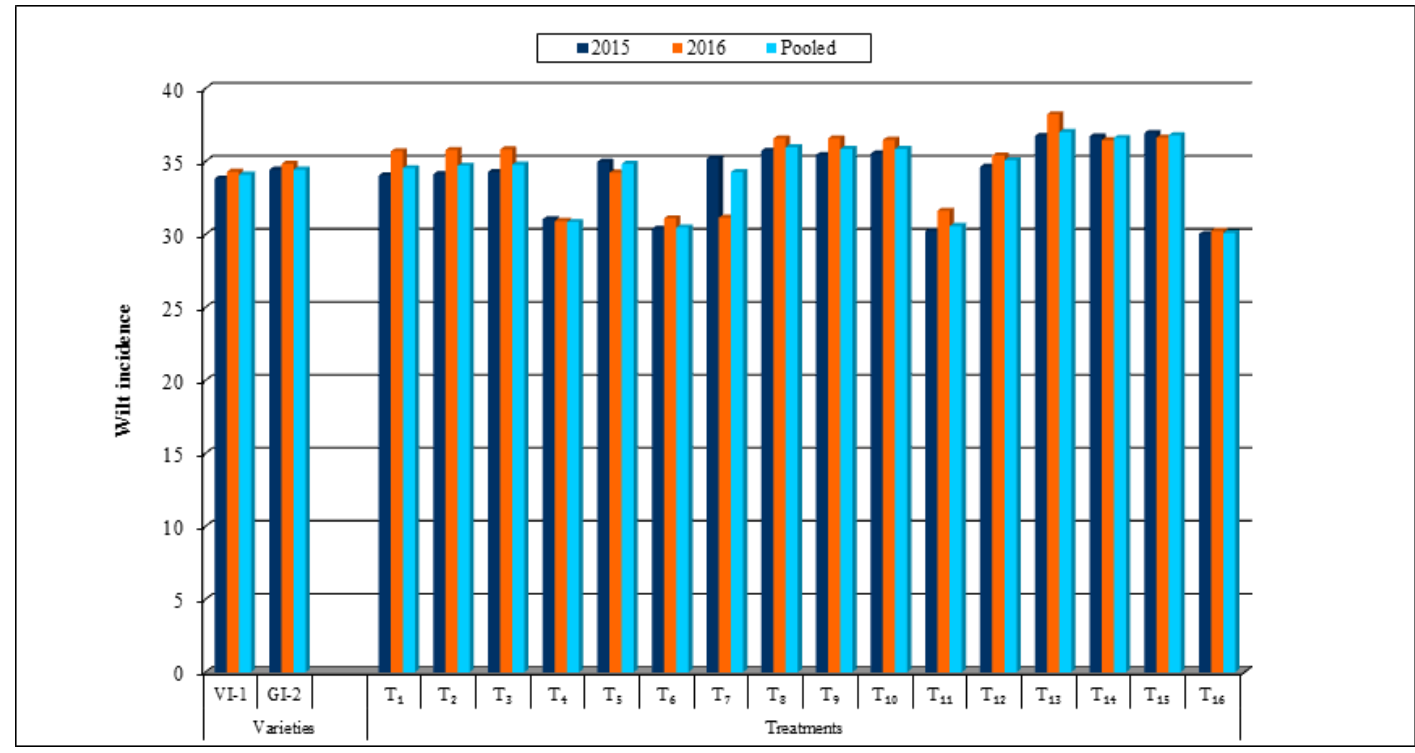

The per cent disease intensity (PDI) was calculated by the formula given by (McKinney, 1923).

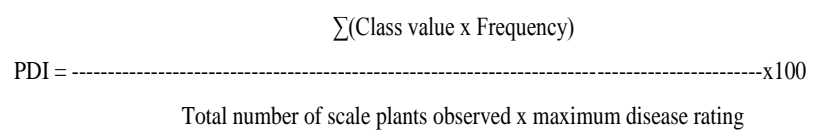

\section{Disease of wilt (Fusarium oxysporum)}

The wilt incidence (Fusarium oxysporum) among Isabgol Varieties (Table 1), as influenced by integrated nutrient management and their interactions at different crop growth stages were recorded (Fig. 1).

The wilt incidence was significantly influenced by varieties (except at 60 DAS during 2016 non significant). The minimum wilt incidence was recorded in Vallabh Isabgol-1 which was on par with Gujarat Isabgol-2, this might be due to varietal characteristic. Similar findings were reported by Kumar et al., (2009).

The wilt infestation influenced by integrated nutrient management minimum was recorded with application of $50 \% \mathrm{RD}$ of FYM $+75 \%$ $\mathrm{RD}$ of $\mathrm{NPK}+$ Azospirillum $+P S B+\mathrm{ZnSO}_{4}+$ $\mathrm{FeSO}_{4}\left(\mathrm{~N}_{16}\right)$ and maximum wilt infestation was recorded by supply of $50 \%$ RD of FYM $+50 \% \mathrm{RD}$ of NPK + Azotobacter $\left(\mathrm{N}_{13}\right)$. The lowest disease incidence could be due to the supplying of organic manures, biofertilizers and NPK which regulates faster release of nutrients to plant helps increase growth attributes, this might have induced tolerance in plant against wilt disease, furthermore application of biofertilizers helps to release phenol content in plant which might have acted as pathogen inhibition (Anon., 2014a).

The wilt infestation influenced by varieties and integrated nutrient management at 90 DAS. Minimum wilt incidence was recorded in Gujarat Isabgol-2, supplied with $50 \% \mathrm{RD}$ of FYM + 75 RD of NPK + Azospirillum + $P S B+\mathrm{ZnSO}_{4}+\mathrm{FeSO}_{4}\left(\mathrm{~V}_{2} \mathrm{~N}_{16}\right)$ and maximum incidence was recorded in Gujarat Isabgol-2, supplied with $50 \%$ RD of FYM + 50\% RD of NPK + Azotobacter $\left(\mathrm{V}_{2} \mathrm{~N}_{13}\right)$ because of the varietal moderately resistance indication and application of above INM treatments, results an good healthy growth of plant. 


\section{References}

Anonymous, 2014a, Annual Report, DMAPR, Anand, p. 39-40.

Goraya, G.S. and Ved, D. K., 2019, Medicinal plants in India: An assessment of their demand and supply, NMPB, Ministry of AYUSH Government of India and ICFRE Dehradun.

Kumar, S. R., Beniwal, B. R. and Choudhary. B. R., 2009, A high yielding Isabgol (Plantago ovata Forsk.) genotype for arid western plain of Rajasthan. Annals of Arid Zone, 48(2): 169-170.

Panse, V. G. and Sukhatme, P. V., 1983, Statistical Methods for Agric. Workers. Indian Council of Agric. Res., New Delhi, pp. 152-174.

Stanford, S. and English., 1963, Use of flame photometer in rapid soils tests for potassium and calcium. Agronomy. J., 41: 446-447.

Mehta, N., Madan, R. L. and Thakur, D. P., 1985, Record of Isabgol wilt from Haryana. Haryana Agric. Univ. J. Res., 15: 473-474.

Elwakil, M. A. and Ghoneem, K. M., 1999, Detection and location of seed borne fungi of blond Psyllium and their transmission in seedlings. Pak. J. Biol. Sci., 2: 38-44.

Mandal, K., Saravanan, R. and Maiti, S., 2008, Effect of different levels of N, P and $\mathrm{K}$ on downy mildew (Peronospora plantaginis) and seed yield of Isabgol (Plantago ovata). Crop Protection, 27: 988-995.

Patel, S. R., Patel M. V. and Parmar. V. R., 2014, Influence of plant height and width on population of aphid, (Aphis gossypii Glover) infesting Isabgol. Trends in Bioscience., 7(24): 4494.

Anonymous, 2015a, Annual Report, DMAPR, Anand, p.43-45.

Talaviya, J. R., Kapadiya, I. B., Bhaliya, C. M. and Lathiya., S. V., 2017, Screening of Cumin Varieties/Lines against Wilt Disease. Intl. J. Curr. Microbiol. App. Sci., 6(6): 3173-3176.

Jat, M. K. and Ahir., R. R., 2017, Management of coriander wilt (Fusarium oxysporum) through plant extracts and source of resistance, $J$. Pharma and Phytochemistry., 6 (4): 1032-1035.

\section{How to cite this article:}

Siddalingayya V. Salimath, K. N. Kattimani, Y. K. Kotikal, D. R. Patile, N. S. Nagarja, Jameel Jhalegar and Venkatesh, J. 2020. Impact of Integrated Nutrient Management on Wilt Incidence of Isabgol (Plantago ovata Forsk.) under Northern Dry Zone of Karnataka. Int.J.Curr.Microbiol.App.Sci. 9(12): 3079-3084. doi: https://doi.org/10.20546/ijcmas.2020.912.365 